\title{
Performance, carcass characteristic and apparent nutrient digestibility of broiler chickens fed Palm-kernel extraction by-products
}

Fafiolu, ${ }^{1}$ A. O., Jegede, ${ }^{1}$, A. V., Teniola, ${ }^{1,2}$, A. A., Olarotimi ${ }^{1}$, I. D., Odukoya, ${ }^{1,2}$, S. O., Alabi $^{1}$, J. O. and Oduguwa ${ }^{1}$, O. O.

${ }^{1}$ Federal University of Agriculture, Abeokuta, College of Animal Science and Livestock Production, Department of Animal Nutrition, P. M. B. 2240, Abeokuta, Nigeria.

${ }^{2}$ Federal College of Animal Health and Production Technology, Department of Animal Production, Moor Plantation, Ibadan, Oyo State, Nigeria. e-mail: fafiolu2000@yahoo.com, fafioluao@unaab.edu.ng

\begin{abstract}
This study aimed at investigating the effect of by-products of palm kernel extraction; palm kernel extraction residue (PKER) and palm kernel sludge (PKS) based diets as replacement for maize in broiler diets. A total of 198 one-day old Marshal Broiler chickens were randomly assigned to six dietary treatments. Each dietary treatment had 33 birds with 11 birds per replicate. Maize in the diets was partly replaced by PKER and PKS each at three levels $(0,10$ and 20\%). The experiment was conducted in both starter and finisher phases. Growth responses, carcass evaluation and nutrient utilization were estimated. Data obtained were subjected to $2 \times 3$ factorial arrangement within the completely randomized design (CRD). Feed: Gain was influenced by the level of the palm kernel by-products during 1-28days of study. The weight gained during the 56 days period were not significantly higher $(P>0.05)$ across the treatments All the carcass parameters measured were not significantly $(P>0.05)$ affected by either PKER or PKS. However birds on PKER diets showed superior $(P<0.05)$ nutrients use. In conclusion, the inclusion of palm kernel extraction by-products (between 10-20\% PKER and 20\% PKS) in the diets of broiler chickens is thereby encouraged for better growth and efficientfeed utilization.
\end{abstract}

Keywords: Nutritive evaluation, Palm kernel, By-products, Broiler Chickens

\section{Introduction}

The persistent decline in the poultry industry and its consequences on the suboptional animal protein consumption is a signal to imminent animal protein malnutrition in different part of the world. There is therefore the need to increase poultry production in order to meet the ever declining protein supply for human. In recent years there has been an increase in growth rate of broiler chickens resulting from genetic improvements, nutrition, disease control and production management (Austic and Neishein, 1990). Modern broiler chickens grow rapidly depositing large proportion of breast and leg muscles as nutritionists combined the knowledge of avian biology with an understanding of nutrient need for growth, production and maintenance of body weight. The manipulation of diets helps to achieve the desired characteristics of growth, carcass composition and reduced fat accumulation in broiler at market age. Oil bearing seeds and fruits are used to raise the energy level of rations for broilers (Say, 1987). The removal of greater parts of the oil from oil seeds leaves residue remaining to be rich in oils (Mc Donald et al., 1987) which are rich in protein and mostly use as plant protein sources in animal feeds.

By-products of palm kernel extraction such 
as palm oil sludge (POS), palm press fibre (PPF) and palm kernel cake (PKC) have been used as feed raw materials or feed ingredients in livestock feeds (Chin, 1991). The primary extractions of palm oil from pericarp of the palm fruit yield the kernel alongside POS and PPF as by-products. The PKC was ranked higher than copra meal but lower than fish meal (FM) and groundnut cake (GNC) in protein value by an earlier work of Devendra (1977). During the mechanical screw press method of extracting oil from palm kernel, other byproducts apart from PKC are obtained. Though information on the use of PKC and PKM are available (Davendra, 1977; Olomu, 1995; Sundu et al. 2005), however there is paucity of information on the use of these by-products especially in monogastric animal nutrition. For the purpose of this study, these by-products are referred to as palm kernel extraction residue (PKER) and palm kernel sludge (PKS). There is therefore the need to evaluate the nutritive value of these two by-products and their effects on the performance, carcass characteristic and nutrient digestibility of broiler chickens.

\section{Materials and methods}

\section{Location}

This study was conducted at the Poultry Unit of Directorate of University Farms, Federal University of Agriculture, Abeokuta, Nigeria. The test ingredients (palm kernel extraction residue PKER and palm kernel sludge PKS) were sourced from a reputable commercial palm kernel extraction company around Abeokuta, Ogun State, Nigeria. No further processing was done on the test ingredients other than extraction of processing after collection from the company.

Processing of test ingredients

The PKER and PKS are obtained during the industrial crushing and extraction of oil from palm kernel nut. PKER is obtained when kernel is crushed to separate oil from cake as a residue at the bottom of uncooked oil, separated from oil by decanting and sieving. PKER has some uncrushed kernel and high oil content. The PKS is obtained as sediment at the bottom of cooking tank and allowed to drain for some hours to remove the bulk of oil from it. The texture and colour of PKS is different from that of PKER due to processing.

Experimental diets and animals

Six experimental diets were formulated using PKER and PKS as energy source and as replacement for maize. The PKER and the PKS were each used at 0,10 and 20\% levels for a two phase study of 56 days study partitioned into 0-28 days and 29-56days. The diets were formulated to supply $12 \mathrm{MJKg}^{-1}$ metabolizable energy and $21 \%$ crude protein for 29-56 days study and the feed were formulated to meet NRC, 1994 requirements.

A total of 198 one-day old broiler chickens $\left(\right.$ Marshall $\left.^{\circledR}\right)$ strain were procured and randomly distributed into six experimental diets. Birds in each of the dietary treatments were further subdivided into 3 replicate groups with eleven (11) birds each. Formulated diets were supplied ad libitum to all experimental birds. Records of feed consumption, body weights were taken for each replicate on weekly basis. These values were then used to evaluate feed intake/bird/day, body weight gain/bird/day and feed conversion ratio for the entire experimental period.

Apparent Nutrient Digestibility

At the end of the feeding trial, two birds from each replicate were selected and transferred into clean, disinfected metabolic cages for a period of three (3) days acclimatization period. A known weight of feed was given to each replicate 
Fafiolu, Jegede, Teniola, Olarotimi, Odukoya, Alabi and Oduguwa

Table 1: Gross composition of experimental diets (0-28 days) \%

\begin{tabular}{lllllll}
\hline & \multicolumn{5}{c}{ Levels of PKER } & \multicolumn{3}{c}{ Levels of PKS } \\
\hline Ingredients & 0 & 10 & 20 & 0 & 10 & 20 \\
Maize & 60.00 & 50.00 & 40.00 & 59.20 & 49.20 & 39.20 \\
Soybean & 30.00 & 30.00 & 30.00 & 30.00 & 30.00 & 30.00 \\
meal & & & & & \\
Fish meal & 2.45 & 2.45 & 2.45 & 2.45 & 2.45 & 2.45 \\
Wheat offal & 3.00 & 3.00 & 3.00 & 3.00 & 3.00 & 3.00 \\
Oyster shell & 2.20 & 2.20 & 2.20 & 2.20 & 2.20 & 2.20 \\
Bone meal & 1.20 & 1.20 & 1.20 & 1.20 & 1.20 & 1.20 \\
DL- & 0.30 & 0.30 & 0.30 & 0.30 & 0.30 & 0.30 \\
Methionine & & & & & & \\
L-Lysine & 0.30 & 0.30 & 0.30 & 0.30 & 0.30 & 0.30 \\
Total Salt & 0.25 & 0.25 & 0.25 & 0.25 & 0.25 & 0.25 \\
Premix* & 0.30 & 0.30 & 0.30 & 0.30 & 0.30 & 0.30 \\
Total & 100.00 & 100.00 & 100.00 & 100.00 & 100.00 & 100.00 \\
Proximate Constituents (Calculated) & & & & \\
Crude protein & 23.73 & 23.55 & 23.52 & 23.72 & 23.56 & 23.35 \\
Crude Fibre & 4.21 & 4.28 & 4.57 & 4.20 & 4.22 & 4.43 \\
Crude fat & 3.85 & 4.65 & 5.03 & 3.85 & 4.25 & 4.81 \\
Ash & 9.64 & 8.85 & 10.15 & 9.64 & 10.12 & 11.02 \\
\hline
\end{tabular}

*Premix composition per $\mathrm{kg}$ diet: Vit A :40000IU, Vit D:80000IU, Vit E:40000ng, Vit $k_{3}: 800 \mathrm{mg}$, Vit $B_{1}: 1000 \mathrm{mg}$, Vit $B_{2}: 6000 \mathrm{mg}$, Vit $B_{\ell}$ VitB12:25mg, Niacin:6000mg, Panthothenic acid:2000mg, Folic acid: 200mg, Biotin:8mg, Manganese:300000mg, Iron:8000mg, Zinc:2 Cobalt:80mg, Iodine:400mg, Selenium:40mg, Choline:800000mg

Table 2: Gross composition of experimental diets for broiler (29-56days)

\begin{tabular}{|c|c|c|c|c|c|c|}
\hline \multirow[b]{2}{*}{ Ingredients } & \multirow[b]{2}{*}{0} & \multicolumn{2}{|c|}{ Levels of PKER } & \multicolumn{3}{|c|}{ Levels of PKS } \\
\hline & & 10 & 20 & 0 & 10 & 20 \\
\hline Maize & 51.00 & 41.00 & 31.00 & 51.00 & 41.00 & 31.00 \\
\hline $\begin{array}{l}\text { Soybean } \\
\text { meal }\end{array}$ & 17.00 & 17.00 & 17.00 & 17.00 & 17.00 & 17.00 \\
\hline $\begin{array}{l}\text { Groundnut } \\
\text { cake meal }\end{array}$ & 16.00 & 16.00 & 16.00 & 16.00 & 16.00 & 16.00 \\
\hline Fish meal & 1.5 & 1.5 & 1.5 & 1.5 & 1.5 & 1.5 \\
\hline Wheat offal & 10.2 & 10.2 & 10.2 & 10.2 & 10.2 & 10.2 \\
\hline Oyster shell & 1.50 & 1.50 & 1.50 & 1.50 & 1.50 & 1.50 \\
\hline Bone meal & 2.10 & 2.10 & 2.10 & 2.10 & 2.10 & 2.10 \\
\hline \multicolumn{7}{|l|}{ Methionine } \\
\hline L-Lysine & 0.10 & 0.10 & 0.10 & 0.10 & 0.10 & 0.10 \\
\hline Table salt & 0.25 & 0.25 & 0.25 & 0.25 & 0.25 & 0.25 \\
\hline Premix* & 0.25 & 0.25 & 0.25 & 0.25 & 0.25 & 0.25 \\
\hline Total & 100.00 & 100.00 & 100.00 & 100.00 & 100.00 & 100.00 \\
\hline \multicolumn{7}{|c|}{ Proximate Constituents (Calculated) } \\
\hline $\begin{array}{l}\text { Crude } \\
\text { protein }\end{array}$ & 20.05 & 20.63 & 21.22 & 20.05 & 20.50 & 20.44 \\
\hline Crude Fibre & 9.77 & 9.87 & 10.35 & 9.77 & 8.84 & 9.92 \\
\hline Crude fat & 4.75 & 5.15 & 5.27 & 4.73 & 5.02 & 5.14 \\
\hline Ash & 7.66 & 7.58 & 6.95 & 7.66 & 7.05 & 6.77 \\
\hline
\end{tabular}


group daily while the droppings were collected daily for three (3) days at twentyfour hours interval. The daily faecal samples collected from each replicate group was weighed, dried in a drying cabinet and then ground. The dried cumulative samples for each replicate over the 3 days collection period were pooled together and thoroughly mixed and samples were kept in desiccators until further analysis to disallow further degradation. Samples were then taken per replicate for laboratory analysis to determine proximate constituents according to AOAC (1995) procedures. Values obtained were then used to calculate the apparent nutrient retention and digestibilities.

\section{Carcass Evaluation}

At the expiration of the feeding trial, one bird per replicate with weight closest to the average of the group was selected, weighed, slaughtered and allowed to bleed thoroughly. The carcass was de-feathered, cleaned, eviscerated and dissected. The cut parts (thigh, drumsticks, breast, back and wings) and organs such as liver, kidney, heart, gizzard, spleen, lungs and were weighed using sensitive scale. Organs weight was expressed in relative to percentage live weight. The lengths, in absolute values, of some part of the gastrointestinal tract (GIT) were measured using a meter rule.

\section{Statistical Analysis}

Experiment was arranged in a $2 \times 3$ factorial within the completely randomized design (CRD) with 3 inclusion levels of either PKER or POS. The data generated from this study were subjected to Analysis of Variance (ANOVA) (SAS, 1999) and significant differences among means were separated using Duncan Multiple Range test at $5 \%$ level of significance.

\section{Results and Discussion}

The results of the proximate composition of the two-products of palm kernel extraction (PKER and PKS) used as test ingredients in this study are presented in Table 3 . The results showed that the by-products of palm kernel extraction were rich sources of crude protein, ether extract and ash. The values for the crude protein in PKER (26.85\%) and POS $(25.48 \%)$ were higher whereas the crude fibre values PKER (13.15\%) and POS $(12.78 \%)$ were lower than those reported by Olomu (1995) and Sundu et al., (2005) for palm kernel cake or meal. PKER has a higher value for crude protein, crude fibre and ether extract than PKS. Improvements in genetic strains overtime may be responsible for differences between report in this study and earlier reports.

Between 0-28 days of experimentation, the source of the palm kernel extraction byproducts has no significant influence $(\mathrm{P}>0.05)$ on all the parameters measured. However between 29-56 days of experimentation, birds fed PKER showed a significant reduction $(\mathrm{P}<0.05)$ in feed intake (FI). The reduction in feed intake may be because of higher energy value of PKER based diets. Generally, birds eat to satisfy energy requirement and will reduce intake drastically as soon as this is satisfied (Ngi, 1999). Moreover, there was no significant $(\mathrm{P}>0.05)$ effect in the final weight, weight gained and feed conversion

Table 3: Proximate composition of the test ingredients (\% DM basis)

\begin{tabular}{lll}
\hline Components & PKER & PKS \\
\hline Dry Matter & 90.08 & 89.95 \\
Crude Protein & 26.85 & 25.48 \\
Crude Fat & 8.88 & 4.66 \\
Ash & 11.88 & 12.05 \\
Crude Fibre & 13.15 & 12.78 \\
Nitrogen free extract & 39.24 & 45.06 \\
\hline
\end{tabular}


although numerically birds on PKER based diets had a higher final weight but lower weight gain and feed conversion than birds on PKS based diets. In all, the overall performance of the experimental birds showed no significant effect $(\mathrm{P}>0.05)$ of the diet on the weight gain, feed intake and feed conversion ratio.

The effect of the levels of inclusion of the palm kernel by-products on performance between 0-28days showed significant $(\mathrm{P}<0.05)$ effect on feed intake. This result may not be easily explained as no particular trend of influence was noticed. Birds on 0 and $20 \%$ inclusion levels had statistically similar $(\mathrm{P}>0.05)$ values which were significantly higher $(\mathrm{P}<0.05)$ than birds on $10 \%$ inclusion levels. Feed conversion was significantly reduced $(\mathrm{P}<0.05)$ for birds on palm kernel by-products compared with the control. This reduction in the feed conversion ratio may have resulted from higher protein content of diets having palm kernel by-products compared with the control since protein functions mainly in the accretion of meat by broilers (Aftab et al., 2006). Also, between 29-56 days of the experiment, final weight, weight gain and feed conversion values were not different among the treatment means. However, feed intake increased significantly $(\mathrm{P}<0.05)$ from $0 \%$ inclusion to $20 \%$ inclusion which may have resulted from increased passage rate of the more fibrous digesta in the small intestine. This observation agreed with the report of Sundu et al. (2006) that hard and fibrous feedstuffs may increase the contraction of the gizzard and may speed up the peristaltic movement of the digesta which could in turn result in increased feed intake.

The results of the carcass evaluation of the birds on the palm kernel by-products are shown in Table 5. Results showed no

Table 4: Performance of broilers fed palm kernel extraction residue (PKER) and palm kernel sludge (PKS) (0-28, 29-56 and 0-56days)

\begin{tabular}{lccccccc}
\hline \multicolumn{7}{c}{ By-product } & \multicolumn{5}{c}{ Inclusion levels } \\
\hline Parameters & PKER & PKS & SEM & 0 & 10 & 20 & SEM \\
\hline $\begin{array}{l}\text { 1-28 days } \\
\begin{array}{l}\text { Weight } \\
\text { gained(g/bird) }\end{array}\end{array}$ & 17.64 & 17.33 & 0.46 & 16.48 & 17.97 & 18.00 & 0.52 \\
$\begin{array}{l}\text { Feed } \\
\text { Intake(g/bird) }\end{array}$ & 51.92 & 51.89 & 0.87 & $53.85^{\mathrm{a}}$ & $49.17^{\mathrm{b}}$ & $52.68^{\mathrm{a}}$ & 0.67 \\
$\begin{array}{l}\text { Feed:Gain } \\
\text { 29.56 days }\end{array}$ & 2.94 & 2.99 & 0.11 & $3.26^{\mathrm{a}}$ & $2.73^{\mathrm{b}}$ & $2.92^{\mathrm{b}}$ & 0.09 \\
$\begin{array}{l}\text { Weight } \\
\text { gained(g/bird) }\end{array}$ & 27.85 & 27.99 & 1.62 & 27.55 & 26.75 & 29.49 & 1.97 \\
$\begin{array}{l}\text { Feed } \\
\text { Intake(g/bird) }\end{array}$ & $123.51^{\mathrm{b}}$ & $125.89^{\mathrm{a}}$ & 1.04 & $124.35^{\mathrm{b}}$ & $122.27^{\mathrm{b}}$ & $127.48^{\mathrm{a}}$ & 1.51 \\
$\begin{array}{l}\text { Feed:Gain } \\
\text { Overall (1-56days) }\end{array}$ & 4.43 & 4.49 & 0.26 & 4.51 & 4.57 & 4.32 & 0.07 \\
$\begin{array}{l}\text { Weight } \\
\text { gained(g/bird) }\end{array}$ & 22.74 & 22.49 & 0.13 & 21.90 & 22.30 & 27.60 & 1.87 \\
$\begin{array}{l}\text { Feed } \\
\text { Intake(g/bird) }\end{array}$ & 87.71 & 88.89 & 0.80 & $89.09^{\mathrm{a}}$ & $85.75^{\mathrm{b}}$ & $90.09^{\mathrm{a}}$ & 1.31 \\
\begin{tabular}{l} 
Feed:Gain \\
\hline ab Means on the same row with different superscript are significantly different $(\mathrm{P}<0.05)$
\end{tabular} & 3.85 & 3.95 & 0.05 & 4.06 & 3.84 & 3.26 & 0.23 \\
\hline
\end{tabular}


Performance characteristic of broiler chickens fed Palm-kernel extraction by-products

Table 5: Carcass evaluation of broilers birds fed palm kernel extraction residue (PKER) and palm kernel sludge (PKS)

\begin{tabular}{|c|c|c|c|c|c|c|c|}
\hline \multirow[b]{2}{*}{ Parameters } & \multicolumn{2}{|c|}{ By-product } & \multicolumn{5}{|c|}{ Inclusion levels } \\
\hline & PKER & PKS & SEM & 0 & 10 & 20 & SEM \\
\hline $\begin{array}{l}\text { Live weight } \\
\text { (g) }\end{array}$ & 1316.67 & 1333.33 & 60.35 & 1233.33 & 1375.00 & 1366.67 & 69.77 \\
\hline $\begin{array}{l}\text { Dressed } \\
\text { weight }(g)\end{array}$ & 890.87 & 912.52 & 44.95 & 832.52 & 936.52 & 936.68 & 52.40 \\
\hline \multicolumn{8}{|l|}{ Cut Parts (\%) } \\
\hline Breast & 15.62 & 16.35 & 0.44 & 15.01 & 16.45 & 16.49 & 0.53 \\
\hline Thighs & 9.61 & 8.14 & 0.31 & 9.21 & 8.98 & 9.34 & 0.43 \\
\hline Drumsticks & 9.39 & 9.56 & 0.23 & 9.35 & 9.45 & 9.65 & 0.29 \\
\hline \multicolumn{8}{|c|}{ Relative Organs (\%) } \\
\hline Liver & 2.49 & 2.63 & 0.15 & 2.61 & 2.74 & 2.32 & 0.19 \\
\hline Kidney & 0.63 & 0.64 & 0.06 & $0.79^{\mathrm{a}}$ & $0.57^{\mathrm{b}}$ & $0.54^{\mathrm{b}}$ & 0.06 \\
\hline Spleen & 0.22 & 0.21 & 0.03 & 0.20 & 0.20 & 0.24 & 0.04 \\
\hline Proventriculus & 0.62 & 0.58 & 0.03 & 0.64 & 0.58 & 0.58 & 0.03 \\
\hline \multicolumn{8}{|c|}{ GIT Morphology (cm) } \\
\hline $\begin{array}{l}\text { Duodenum } \\
\text { fold length }\end{array}$ & 15.28 & 15.23 & 1.20 & 15.67 & 15.82 & 14.28 & 1.35 \\
\hline $\begin{array}{l}\text { Duodenum } \\
\text { width }\end{array}$ & 2.17 & 1.86 & 0.28 & 2.17 & 1.81 & 2.07 & 0.35 \\
\hline $\begin{array}{l}\text { Caecum } \\
\text { length }\end{array}$ & 16.36 & 17.46 & 0.53 & 17.55 & 17.18 & 15.98 & 0.64 \\
\hline Caecum width & 0.94 & 0.91 & 0.12 & 1.03 & 1.68 & 1.07 & 0.13 \\
\hline Ileum length & 70.94 & 72.83 & 3.35 & 69.67 & 74.58 & 71.42 & 4.15 \\
\hline
\end{tabular}

${ }^{a b}$ Means on the same row with different superscript are significantly different $(\mathrm{P}<0.05)$

significant effect $(\mathrm{P}>0.05)$ in the weight of the cut up parts, dressed weight, harvested organs and length of the gastro-intestinal tract measured across treatments. A significant decrease in the weight of the kidney was observed as the level of the byproducts increased in the diets. No feasible explanation could be given for this observation within the limit of the facts available to us in this experiment.

Table 6 shows the effect of palm kernel byproducts on the digestibility of proximate constituents. Results showed that PKER had a significantly $(\mathrm{P}<0.05)$ higher apparent digestibility, digestible dry matter, crude protein, ether extract, ash, nitrogen free extract and Metabolisable energy. This may be due to higher protein and higher oil content of the PKER based diets. The increase in the crude protein digestibility could be an indication of higher availability of the amino acids present in the palm kernel by-products. Nwokolo et al. (1976) and Sundu et al. (2006) reported that palm kernel meals have higher amino acid availability. This may have been further enhanced by the heat treatment during the extrusion procedures. Birds on 10 and $20 \%$ inclusion levels had similar value for the ether extract and this was significantly higher $(\mathrm{P}<0.05)$ than for birds on $0 \%$ inclusion. Oils and fats are highly digestible, therefore higher oil content with the level of palm kernel could be 
Table 6: Digestibility coefficients of broilers fed palm kernel extraction residue (PKER) and palm kernel sludge (PKS)

\begin{tabular}{llllllll}
\hline Parameters & PKER & PKS & SEM & 0 & 10 & 20 & SEM \\
\hline $\begin{array}{l}\text { Dry matter } \\
\text { Crude }\end{array}$ & $0.78^{\mathrm{a}}$ & $0.75^{\mathrm{b}}$ & 0.008 & $0.72^{\mathrm{b}}$ & $0.75^{\mathrm{a}}$ & $0.76^{\mathrm{a}}$ & 0.009 \\
$\begin{array}{l}\text { Protein } \\
\text { Ether }\end{array}$ & $0.73^{\mathrm{b}}$ & 0.008 & $0.72^{\mathrm{b}}$ & $0.75^{\mathrm{a}}$ & $0.76^{\mathrm{a}}$ & 0.009 \\
Extract & & $0.92^{\mathrm{b}}$ & 0.004 & $0.90^{\mathrm{b}}$ & $0.91^{\mathrm{a}}$ & $0.92^{\mathrm{a}}$ & 0.009 \\
Ash & $0.59^{\mathrm{a}}$ & $0.53^{\mathrm{b}}$ & 0.013 & 0.55 & 0.56 & 0.57 & 0.004 \\
Crude & 0.70 & 0.68 & 0.014 & 0.68 & 0.68 & 0.71 & 0.014 \\
Fibre & & & & & & & \\
NFE & $0.83^{\mathrm{a}}$ & $0.79^{\mathrm{b}}$ & 0.006 & 0.80 & 0.81 & 0.81 & 0.009 \\
ME & $0.82^{\mathrm{a}}$ & $0.79^{\mathrm{b}}$ & 0.006 & 0.79 & 0.81 & 0.81 & 0.008 \\
\hline
\end{tabular}

${ }^{a b}$ Means on the same row with different superscript are significantly different $(\mathrm{P}<0.05)$

responsible for higher digestibility of ether extract. This is in line with the observation of Voigt et al.(2006)

\section{Conclusion}

From the foregoing, the growth performance of the experimental birds was not affected by the inclusion of the palmkernel by-products. Nutrient digestibility was better on the birds consuming PKER than birds on PKS. Carcass evaluation of birds on the palm-kernel by-products was not affected when maize was replaced up to $20 \%$ by palm-kernel by-products.

Therefore palm-kernel extraction byproducts can be included in broiler diets to replace maize between $10-20 \%$. Enhancement of the by-products using contemporary innovations is also advocated for improved performance.

\section{References}

Aftab, U., Ashraf, M. and Jiang, Z. 2006. Low Protein Diets for Broilers. World Poultry Science Journal. 62:688-698

AOAC. 1995. Methods 43290, Official Method of Analysis of the Association of Analytical Chemist. $16^{\text {th }}$ edition. Washington DC.

Austic, R. E. and Nesheim, M. C. 1990.
Poultry Production. $13^{\text {th }}$ edition. Lea and Febiger, Philadephis, P. A.

Chin. F. Y. 1991. Oil Palm: A Rich Source of Animal Feed. In: Asian Livestock. PHCA Publication. Bangkok, Thailand

Devendra, C. 1997. Utilization of feeding stuffs from Oil palm. In: feeding stuffs for Livestock in South East Asia. Pp 116-131

McDonald, P., Edwards, R. A., Greenhalgh, J. F. D and Morgan, C. A. 1998. Animal Nutrition, $5^{\text {th }}$ edition, $\left(3^{\text {rd }}\right.$ reprint). Longman Scientific and Technical Publisher

National Research Council (NRC). 1994. Composition of feedstuffs used in poultry diets. In: Nutrient requirement of poultry. $9^{\text {th }}$ revised edition. National Academic Press. Washington DC. Pp 61-68

Ngi, J. 1999. The effect of crumbs versus all mash broiler starter on broiler chicken performance. B. Agric Project. University of Agriculture, Makurdi, Nigeria

Nwokolo, E, N., Biagg, D. B. and Saben, H. S. 1976. The availability of amino acids from palm kernel, soyabean, cotton seed and rape seed meal for the 
Performance characteristic of broiler chickens fed Palm-kernel extraction by-products

growing chicks. Poultry Science, 55: 2300-2304

Olomu, J. M. 1995. Monogastric Animal Nutrition. Principles and Practice. A Jachem Publication, Benin, Nigeria. Pp 68-69

SAS Institute. 1999. SAS Users Guide: Statistics. Version 6, Fourth Edition. SAS Institute, Cary, NC.

Say, R. R. 1997. Manual of Poultry Production in the Tropics. CAB International Publisher. Great Britain. Pp 46- 49

Sundu, B., Kumar, A. and Dingle, J. 2005. Response of birds fed increasing levels of palm kernel meal supplemented with enzymes. Australian Poultry Science Symposium, 17:227-228

Sundu, B., Kumar, A. and Dingle, J. 2006. Palm kernel meal in broiler diet. Effect on chicken performance and health. World Poultry Science Journal. 62:316-325

Voigt, J.,S. Kuhla, K. Gaafar, M. Derno, and Hagemeister, H. 2006. Digestibility of rumen protected fat in cattle. Slovak Journal of Animal Science, 39, 2006 (1-2): 16 - 19

Received: $13^{\text {th }}$ March, 2014

Accepted: $28^{\text {th }}$ February, 2015 